\title{
The nutrition and health transition in the North West Province of South Africa: a review of the THUSA (Transition and Health during Urbanisation of South Africans) study
}

\author{
Hester H Vorster ${ }^{1, *}$, Christina S Venter ${ }^{1}$, Marié P Wissing ${ }^{2}$ and Barrie M Margetts ${ }^{1}$ \\ ${ }^{1}$ School of Physiology and Nutrition, North-West University (Potchefstroom Campus), Private Bag X6001, \\ Potchefstroom 2520, Republic of South Africa: ${ }^{2}$ School of Psycho-Social and Behavioural Sciences, North-West \\ University (Potchefstroom Campus), Potchefstroom, Republic of South Africa
}

Submitted 15 May 2005: Accepted 29 May 2005

\begin{abstract}
Objective: To describe how urbanisation influences the nutrition and health transition in South Africa by using data from the THUSA (Transition and Health during Urbanisation of South Africans) study.

Design: The THUSA study was a cross-sectional, comparative, population-based survey.

Setting: The North West Province of South Africa.

Subjects: In total, 1854 apparently healthy volunteers, men and women aged 15 years and older, from 37 randomly selected sites. Pregnant and lactating women, those with diagnosed chronic diseases and taking medication, with acute infections or inebriated were excluded but screened for hypertension and diabetes mellitus. Subjects were stratified into five groups representing different levels of urbanisation in rural and urban areas: namely, deep rural, farms, squatter camps, townships and towns/cities. Outcome measures and methods: Socio-economic and education profiles, dietary patterns, nutrient intakes, anthropometric and biochemical nutrition status, physical and mental health indicators, and risk factors for non-communicable diseases (NCDs) were measured using questionnaires developed or adapted and validated for this population, as well as appropriate, standardised methods for the biochemical analyses of biological samples.

Results: Subjects from the rural groups had lower household incomes, less formal education, were shorter and had lower body mass indices than those in the urban groups. Urban subjects consumed less maize porridge but more fruits, vegetables, animal-derived foods and fats and oils than rural subjects. Comparing women from rural group 1 with the urban group 5, the following shifts in nutrient intakes were observed: \% energy from carbohydrates, 67.4 to 57.3; from fats, 23.6 to 31.8; from protein, 11.4 to 13.4 (with an increase in animal protein from 22.2 to $42.6 \mathrm{~g} \mathrm{day}^{-1}$ ); dietary fibre, 15.8 to $17.7 \mathrm{~g} \mathrm{day}^{-1}$; calcium, 348 to $512 \mathrm{mg} \mathrm{day}^{-1}$; iron from 8.4 to $10.4 \mathrm{mg} \mathrm{day}^{-1}$; vitamin A from 573 to $1246 \mu \mathrm{g}$ retinol equivalents day ${ }^{-1}$; and ascorbic acid from 30 to $83 \mathrm{mg} \mathrm{day}^{-1}$. Serum total cholesterol, low-density lipoprotein cholesterol and plasma fibrinogen increased significantly across groups; systolic blood pressure $>140 \mathrm{mmHg}$ was observed in $10.4-34.8 \%$ of subjects in different groups and diabetes mellitus in $0.8-6.0 \%$ of subjects. Women in groups 1 to 5 had overweight plus obesity rates of 48, 53, 47, 61 and 61\%, showing an increase with urbanisation. Subjects from group 2 (farm dwellers) showed the highest scores of psychopathology and the lowest scores of psychological well-being. The same subjects consistently showed the lowest nutrition status.

Conclusions: Urbanisation of Africans in the North West Province is accompanied by an improvement in micronutrient intakes and status, but also by increases in overweight, obesity and several risk factors for NCDs. It is recommended that intervention programmes to promote nutritional health should aim to improve micronutrient status further without leading to obesity. The role of psychological strengths in preventing the adverse effects of urbanisation on health needs to be examined in more detail.
\end{abstract}

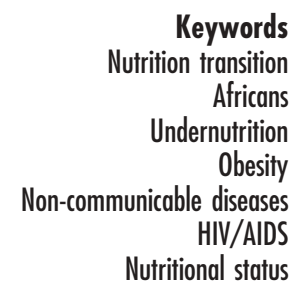


THUSA is a Setswana word meaning 'help'. But it is also an acronym for Transition and Health during Urbanisation of South Africans. The THUSA study was motivated by the rapid urbanisation of Africans in South Africa ${ }^{1}$. This urbanisation is accompanied by acculturation and modernisation and is probably associated with the present triple burden of morbidity and mortality in South Africa ${ }^{2}$ : infectious diseases including HIV/AIDS; non-communicable diseases (NCDs); and violence and injuries. The THUSA study was designed to examine the changes in health determinants during urbanisation of Africans in the North West Province, with the aims to inform preventive strategies, policy and programmes and to identify areas that need further research.

The objectives of the present paper are to describe the development of the design and methodologies of the THUSA study, to review some of the main findings and to show how these findings motivated follow-up actions (interventions) and further research.

\section{Methods}

\section{Study design and subjects}

A conceptual framework was developed for the study ${ }^{3,4}$ by identifying from the literature potential exposures and outcomes that should be measured to describe the determinants of health during urbanisation. The aim of the study was not to report on prevalence of diseases and their risk factors and a total randomised sample was not necessary. Available resources and the urgent need for information argued against a prospective study at the time. Therefore, it was decided to use a cross-sectional comparative design in which a research team consisting of scientists from both the natural and social sciences and Setswana-speaking fieldworkers used both qualitative and quantitative methods to gather information. The statistical consultation services of the North-West University helped to design a model for subject recruitment, based on data of population density, ensuring that subjects from all levels or stages of urbanisation would be included, and that statistical power would be reached to show significant differences between subject groups. A community-based sample of 1854 apparently healthy men and women volunteers was recruited from 37 randomly selected sites representing all health districts in the Province. Pregnant and lactating women, subjects younger than 15 years, those suffering from known and diagnosed diseases, those taking any form of chronic medication, inebriated subjects and those with temperature above $37^{\circ} \mathrm{C}$ were excluded. Subjects were grouped into five groups, representing five levels or stages of urbanisation based mainly on where subjects lived and their jobs. Group 1 consisted of rural people living in traditional African villages with a tribal head. Group 2 comprised farm dwellers, living and working on commercial farms. Group 3 subjects lived in informal housing areas or 'squatter camps' adjacent to all major towns and cities. These subjects moved to the informal housing areas recently from mainly rural areas and represent subjects in the most rapid phase of transition. Group 4 were volunteers from the old established African townships with brick houses, running water and electricity available, who worked as labourers in various institutions and industries. Group 5 represented the 'upper class' urban subjects consisting of professional people (teachers, nurses), government employees, politicians and from businesses/corporate industrial environments. Groups 1 and 2 can be regarded as rural, group 3 as transitional, and groups 4 and 5 as urban.

\section{Ethical considerations}

The Ethics Committee of the University approved the study (approval no. 4M5-95). Subjects were fully informed about the study in their home language and signed an informed consent form (some with a cross). Parents or legal guardians signed for subjects younger than 21 years. Subjects identified with hypertension, diabetes mellitus, anaemia or other abnormalities were referred for treatment.

Volunteers who did not meet the inclusion criteria were screened for hypertension and diabetes mellitus. Subjects received lunch after blood samples were taken and their travel expenses were paid. Permission to do the study was also obtained from tribal heads, community leaders and the North West Department of Health, to ensure cooperation of all stakeholders.

\section{Questionnaires}

All questionnaires used were specifically designed or adapted for this study population and validated with appropriate methods in the population. Research staff and fieldworkers were trained to apply the questionnaires during individual interviews in the language of the subject's choice.

1. Demographic questionnaire. Information on type of housing, access to electricity, water source, sanitation, income, health history, family structures, education, lifestyle, etc. was obtained during individual interviews.

2. Quantitative food frequency questionnaire (QFFQ). The QFFQ was validated by Macintyre et $a l^{5-8}$. Food data were translated into nutrient data using a program based on the South African food composition tables 9 and underreported energy intakes adjusted using the method of Willett et al. ${ }^{10}$.

3. Activity questionnaire. Habitual physical activity was measured by a questionnaire designed and validated for this population by Kruger et al. ${ }^{11}$, and applied by Masters students who could speak Setswana.

4. Psychological questionnaires. Existing scales and quesionnaires $^{12-23}$ were adapted and validated by clinical psychologists and their graduate students to measure psychosocial variables such as general symptoms of psychopathology and negativity (anxiety, 
depression, social dysfunction, somatic symptoms), hostility, impulsiveness, resentment and aggression, as well as positive indications of psychosocial well-being (sense of coherence and satisfaction with life). Coping strategies (active coping, seeking social support, religion, focusing on and venting emotion, disengagement, antisocial and aggressive action), perceived social support, perceived stress, degree of acculturation and individualism versus collectivism were also measured.

5. Other questionnaires. A number of validated structured and open-ended questionnaires were designed, validated and used to obtain information on household food security ${ }^{24}$, knowledge and attitudes towards obesity, reproductive behaviour, parity, breast-feeding $^{25}$ and colorectal cancer risk ${ }^{26}$ in sub-samples.

\section{Biological measurements and methods}

The different measurements and methods used to obtain information on health status and contributing factors have been described in detail in a number of publications ${ }^{4-}$ $8,11,24-32$. These measurements included anthropometry (weight, height, body circumferences and skinfold thicknesses), clinical examinations (signs of malnutrition, oral temperature, blood pressure), glucose tolerance tests (2-hour, $75 \mathrm{~g}$ glucose load), collection of blood, urine and cell samples (for serum, plasma, DNA preparation and HIV testing), cardiovascular reactivity tests (laboratory stressor and Finapres ${ }^{\circledR}$ measurements), bone stiffness ${ }^{27}$ and biochemical analyses of serum and plasma samples with standardised methodology in different specialised laboratories for about 50 different variables indicative of nutrition and health status and NCD risk.

\section{Statistical analyses}

The Statistica program (StatSoft Inc., Tulsa, OK, USA) and SPSS package (SPSS Inc., Chicago, IL, USA) were used to calculate means, medians, standard deviations, standard errors and 95\% confidence intervals. Data not normally distributed were logarithmically transformed and nonparametric tests used to test for significant differences between groups. Univariate analysis of variance, the post hoc test for least significant differences, multivariate regression analysis, stepwise regression models, Spearman rank-order correlations with adjustment for confounding factors and principal components analysis were done where appropriate for the different publications, each with a specific focus that resulted from the THUSA study ${ }^{4-8,11,24-32}$.

\section{Results}

From the large variety of variables and information generated by the THUSA study, a selection was made for this paper to describe the population and the five groups of subjects at different stages of urbanisation (Table 1) and to illustrate the observed changes in dietary patterns (Tables 2 and 3), nutrient intakes (Table 4), nutritional status (Table 5), as well as the emergence of risk factors for NCDs (Tables 6 and 7).

\section{The subjects}

Table 1 shows that the sizes of the households on farms tended to be smaller (possibly because children were sent away to schools or families with food security $)^{4,24}$. The majority of rural households had very low to low incomes while subjects from urban households reported moderate to high incomes (groups 4 and 5, 58.1 and 75.6\%). Only 38.8 and $12.4 \%$ of the rural subjects, but 55.7 and $98.5 \%$ of the urban subjects had more than 8 years of schooling accompanied by training for a job. The mean height of both men and women increased across the groups, with subjects in group 5 being significantly taller than those in the other four groups ${ }^{4}$. The gradual increase in body mass index (BMI) from groups 1 to 5 was not significant ${ }^{4}$. Table 1 also shows the percentage of subjects infected with HIV (from 5.8 to $17.7 \%$ in the different groups) and the large percentage of men who smoked cigarettes ( $42.3 \%$ in group 5 and $66.5 \%$ in group 2). The psychopathology scores of group 5 were the lowest, while group 2 (farm dwellers) was the most vulnerable, having the highest scores for all three scales. In accordance, the psychological well-being scores were the highest in groups 4 and 5 and the lowest in the two rural groups (1 and 2).

\section{Changes in dietary patterns}

Table 2 lists the food items eaten by most of the subjects ( $>85 \%$ of a group). To simplify the table, only data for women are given here, but similar observations were made for men ${ }^{28}$. Table 2 shows that while $100 \%$ of subjects in group 1 ate the staple maize porridge daily, and 99\% in groups 2 and 3, and 98\% in group 4, only 90\% in group 5 regularly ate it. Moreover, the daily portion size decreased from 450 and $530 \mathrm{~g}$ in the two rural groups, to 362 and $193 \mathrm{~g}$ in the urban groups. Sugar intake remained stable across strata well as the ingredients of a stew (cabbage, onion, tomato and oil) usually eaten with maize porridge or rice. Only in the urban groups did fruit (banana and apple) as well as milk appear in the list of top 10 foods eaten by more than $85 \%$ of the group.

Table 3 further demonstrates changes in dietary patterns by showing the differences between groups in the percentage contribution of specific foods and food groups to total energy intake. Carbohydrate-rich foods contributed $67.4 \%$ of total energy in group 1 and only $47.8 \%$ in group 5 . Group 1 obtained $19.9 \%$ of their energy from animal protein foods (meat, chicken, fish, eggs and milk) compared with $33.3 \%$ of group 5 . There was a striking increase in the contribution of fruit and vegetables to energy consumption: 6.2, 6.5, 8.0, 9.2 and $10.8 \%$ in groups $1,2,3,4$ and 5 , respectively. 
Table 1 Socio-economic, educational and physical and mental health indicators by group

\begin{tabular}{|c|c|c|c|c|c|}
\hline Variable/indicator & $\begin{array}{c}\text { Group } 1 \text { (196 men, } \\
300 \text { women) }\end{array}$ & $\begin{array}{c}\text { Group } 2 \text { (113 men, } \\
148 \text { women) }\end{array}$ & $\begin{array}{c}\text { Group } 3 \text { (134 men, } \\
175 \text { women) }\end{array}$ & $\begin{array}{c}\text { Group } 4 \text { (236 men, } \\
293 \text { women) }\end{array}$ & $\begin{array}{c}\text { Group } 5 \text { (84 men, } \\
106 \text { women) }\end{array}$ \\
\hline$\%$ Households with $\leq 4$ members & 46.5 & 70.5 & 44.9 & 52.0 & 62.5 \\
\hline$\%$ Households with $\geq 9$ members & 8.9 & 0.0 & 4.1 & 3.6 & 6.3 \\
\hline Very low household income* (\%) & 23.9 & 11.2 & 19.8 & 14.1 & 19.9 \\
\hline Low household income* $(\%)$ & 30.0 & 50.9 & 35.1 & 27.1 & 4.7 \\
\hline Medium household income* (\%) & 42.5 & 38.1 & 43.6 & 52.2 & 40.3 \\
\hline High household income* $(\%)$ & 2.9 & 0 & 1.7 & 5.9 & 35.3 \\
\hline No formal education (\%) & 27.7 & 42.2 & 23.1 & 13.0 & 0 \\
\hline$<8$ years school $(\%)$ & 33.7 & 45.5 & 33.2 & 31.9 & 1.6 \\
\hline$>8$ years school \& trade $(\%)$ & 38.8 & 12.4 & 43.7 & 55.7 & 98.5 \\
\hline \multicolumn{6}{|l|}{ Height $(\mathrm{cm})$, mean $(95 \% \mathrm{Cl})$} \\
\hline Men & $167.1^{\mathrm{ab}}(166-168)$ & $167.6^{c}(167-169)$ & $168.0^{d}(167-169)$ & $168.6^{a}(168-170)$ & $170.3^{\mathrm{bcd}}(168-172)$ \\
\hline Women & $157.3^{a}(157-158)$ & $157.0^{b}(156-158)$ & $158.4^{\mathrm{C}}(157-159)$ & $157.1^{c}(156-158)$ & $159.1^{\mathrm{abc}}(158-160)$ \\
\hline \multicolumn{6}{|l|}{ BMI $\left(\mathrm{kg} \mathrm{m}^{-2}\right)$, mean $(95 \% \mathrm{Cl})$} \\
\hline Men & 20.7 (20.2-21.3) & $20.6(19.9-21.3)$ & $20.3(19.7-20.9)$ & $21.3(20.8-21.8)$ & $23.1(22.2-24.0)$ \\
\hline Women & $25.6(24.8-26.3)$ & $26.3(25.2-27.4)$ & $26.7(25.7-27.7)$ & $28.0(27.3-28.8)$ & $28.1(26.7-29.4)$ \\
\hline \multicolumn{6}{|l|}{$\%$ HIV-infected } \\
\hline Men & 7.4 & 7.8 & 11.1 & 21.9 & 5.8 \\
\hline Women & 8.9 & 8.6 & 17.7 & 12.7 & 9.4 \\
\hline \multicolumn{6}{|l|}{$\%$ Smokers } \\
\hline Men & 48.6 & 66.5 & 63.2 & 60.7 & 42.3 \\
\hline Women & 19.8 & 27.3 & 20.7 & 11.5 & 1.0 \\
\hline \multicolumn{6}{|l|}{ Psychopathology } \\
\hline GHQ-T & 9.3 & 10.6 & 8.6 & 9.5 & 4.7 \\
\hline NEO-PI-R:N & 166.6 & 178.4 & 166.3 & 169.9 & 156.3 \\
\hline BD-T & 43.3 & 46.4 & 44.0 & 45.0 & 42.9 \\
\hline \multicolumn{6}{|l|}{ Psychological well-being } \\
\hline SOC & 120.1 & 120.2 & 122.8 & 122.9 & 137.7 \\
\hline PNB & 7.6 & 8.1 & 8.2 & 9.8 & 15.8 \\
\hline SWLS & 21.1 & 21.3 & 22.6 & 23.3 & 22.4 \\
\hline
\end{tabular}

Adapted from Vorster et al. ${ }^{4}$.

$\mathrm{Cl}$ - confidence interval; BMI - body mass index; GHQ-T - General Health Questionnaire total score; NEO-PI-R:N - Neuroticism domain scale of the NEO Personality Inventory; BD-T - Buss Durkee Hostility Scale total score; SOC - Sense of Coherence Scale; PNB - Positive-Negative-Affect Balance; SWLS - Satisfaction with Life Scale.

*Very low household income - R0-R100 per month; low household income - R101-R500 per month; medium household income - R501-R3000 per month; high household income - R3000 + per month.

a-d Mean values with the same superscript letter differ significantly $(P \leq 0.05)$.

The above pattern was also observed in $\operatorname{men}^{28}$, with the exception of the much higher contribution alcohol made to total energy intake in men (shown at the bottom of Table 3) than in women.

\section{Nutrient intakes}

The mean intakes of selected nutrients given in Table 4 illustrate the observed changes in dietary patterns. The percentage of energy obtained from carbohydrates decreased gradually across groups in both men and women with about 10\% difference between groups 1 and 5 . The total fat intake contributed between 22.6 and $23.6 \%$ of energy in the two rural groups, while it was $30.6 \%$ (men) and $31.8 \%$ (women) in group 5 . The percentage of energy from protein also increased gradually with urbanisation, but Table 4 clearly demonstrates that this was because of a very high increase in animal protein intake: from 25.9 and $22.2 \mathrm{~g} \mathrm{day}^{-1}$ in men and women of group 1, to 44.4 and $42.6 \mathrm{~g} \mathrm{day}^{-1}$ in the urban men and women of group 5. The increase in animal foods is reflected in increases in cholesterol intake and decreases in the ratio of polyunsaturated to saturated fatty acids (P/S). Slight increases in dietary fibre intakes were observed from rural to urban subjects. Some selected mineral and vitamin intakes are also shown in Table 4, to demonstrate the trend that micronutrient intakes improved from rural to urban groups. It is especially notable that the lowest mean micronutrient intakes are often seen in the men and women of group 2 (the farm dwellers). Differences between groups were statistically significant for most of these nutrients ${ }^{28}$.

\section{Nutritional status}

Table 5 gives data on some nutritional status variables of men and women in the respective groups ${ }^{29,30}$. The percentages of men with low to normal BMI $(<18.0-$ $24.9 \mathrm{~kg} \mathrm{~m}^{-2}$ ) were higher than in women, while the percentages of women who were obese (BMI $\geq 30.0 \mathrm{~kg} \mathrm{~m}^{-2}$ ) were much higher (five to 10 times) than those of the men in each group. In group 4, 36.3\% of the women were obese. The biochemical indicators of nutritional status in Table 4 illustrate that the urban subjects generally had better micronutrient status than the rural ones. The differences between groups for total iron-binding capacity, transferrin saturation and haemoglobin were significant ${ }^{30}$. Serum retinol was significantly higher in men of group $5^{30}$ than in groups 1,2 and 4. 
Table 2 Changes in dietary patterns: top 10 foods consumed by $>85 \%$ of women in the different groups

\begin{tabular}{|c|c|c|c|c|c|}
\hline Food & Group 1 & Group 2 & Group 3 & Group 4 & Group 5 \\
\hline \multicolumn{6}{|l|}{ Maize meal porridge } \\
\hline$\%$ of consumers & 100 & 99 & 99 & 98 & 90 \\
\hline Portion size $(\mathrm{g})^{*}$ & $450(350)$ & $530(528)$ & $400(330)$ & $362(280)$ & $193(180)$ \\
\hline \multicolumn{6}{|l|}{ Sugar, white } \\
\hline$\%$ of consumers & 98 & 97 & 100 & 100 & 96 \\
\hline Portion size (g) & $35(40)$ & $30(29)$ & $29(27)$ & $285(30)$ & $31(29)$ \\
\hline \multicolumn{6}{|l|}{ Onion, cooked } \\
\hline$\%$ of consumers & 98 & 93 & 99 & 97 & 96 \\
\hline Portion size (g) & $8(7.1)$ & $6.9(6.3)$ & $7.4(7.0)$ & $8.5(6.7)$ & $8.7(6.4)$ \\
\hline \multicolumn{6}{|l|}{ Rice, white } \\
\hline$\%$ of consumers & & 95 & 98 & 98 & 95 \\
\hline Portion size (g) & $35(36)$ & $36(31)$ & $46(48)$ & $44(36)$ & 49 (39) \\
\hline \multicolumn{6}{|l|}{ Cabbage, cooked } \\
\hline$\%$ of consumers & & 93 & 94 & 94 & 92 \\
\hline Portion size (g) & $8(10)$ & $7.3(8)$ & $7.7(7.6)$ & $8.7(10)$ & \\
\hline \multicolumn{6}{|l|}{ Sunflower oil } \\
\hline$\%$ of consumers & 95 & 88 & 97 & 98 & 91 \\
\hline Portion size (g) & $3.5(3.8)$ & $3.3(2.3)$ & $3.1(2.3)$ & $3.6(2.7)$ & $4.0(2.3)$ \\
\hline \multicolumn{6}{|l|}{ Tomato, cooked } \\
\hline$\%$ of consumers & 93 & 86 & 97 & 92 & 88 \\
\hline Portion size (g) & $10(10)$ & $9.1(8.5)$ & $9(8.8)$ & $10.7(10.1)$ & $11.5(8.4)$ \\
\hline \multicolumn{6}{|l|}{ Bread, white } \\
\hline$\%$ of consumers & 91 & 87 & 92 & 94 & \\
\hline Portion size (g) & $27(36)$ & $35(42)$ & $32(45)$ & $33.6(58.1)$ & \\
\hline \multicolumn{6}{|l|}{ Margarine, hard } \\
\hline$\%$ of consumers & 91 & 85 & & 93 & 87 \\
\hline Portion size (g) & $3.5(4.0)$ & $3.6(4.6)$ & & $5.6(6.7)$ & $6.2(6)$ \\
\hline \multicolumn{6}{|l|}{ Samp } \\
\hline$\%$ of consumers & 85 & & & & \\
\hline Portion size (g) & $38(41.4)$ & & & & \\
\hline \multicolumn{6}{|l|}{ Banana } \\
\hline$\%$ of consumers & & 82 & 82 & & \\
\hline Portion size $(\mathrm{g})$ & & $16(25)$ & 31 (33) & & \\
\hline \multicolumn{6}{|l|}{ Milk (whole, fresh) } \\
\hline$\%$ of consumers & & & & 85 & 91 \\
\hline Portion size $(\mathrm{g})$ & & & & $134(113)$ & $156(123)$ \\
\hline \multicolumn{6}{|l|}{ Apple } \\
\hline$\%$ of consumers & & & & & 89 \\
\hline Portion size (g) & & & & & $75(64)$ \\
\hline
\end{tabular}

Adapted from MacIntyre et al. ${ }^{28}$.

${ }^{\star}$ Mean (standard deviation) portion size of food for responders who consumed the food.

Table 3 Changes in dietary patterns: mean percentage (standard deviation) contribution of different foods to total energy consumption of women by group

\begin{tabular}{|c|c|c|c|c|c|}
\hline Food groups/foods & Group $1(n=290)$ & Group $2(n=148)$ & Group $3(n=172)$ & Group $4(n=292)$ & Group $5(n=106)$ \\
\hline \multicolumn{6}{|l|}{ Carbohydrate-rich foods } \\
\hline Maize meal & $27.7^{a}(17.3)$ & $31.6^{\mathrm{b}}(17.3)$ & $23.4^{\mathrm{c}}(15.9)$ & $20.1^{d}(14.6)$ & $11.0^{\mathrm{abcd}}(10.6)$ \\
\hline Bread & $11.5(8.4)$ & $11.8(8.4)$ & $12.8(9.3)$ & $12.7(8.4)$ & $11.3(7.7)$ \\
\hline Other cereal foods & $18.5(5.0)$ & $15.6(4.7)$ & $20.9(6.3)$ & $17.7(4.7)$ & $15.6(3.4)$ \\
\hline Sugar (added) & $6.8(6.5)$ & $6.2(6.4)$ & $6.5(6.1)$ & $5.9(5.7)$ & $5.5(4.4)$ \\
\hline Miscellaneous sweets & $2.9(4.4)$ & $3.3(5.3)$ & $3.4(3.9)$ & $3.8(3.8)$ & $4.4(5.2)$ \\
\hline \multicolumn{6}{|l|}{ Protein-rich foods } \\
\hline Meat, chicken, fish, eggs & $12.8^{\mathrm{ae}}(3.3)$ & $12.1^{\text {bf }}(3.4)$ & $17.5^{\mathrm{ce}}(3.9)$ & $18.0^{\mathrm{df}}(4.0)$ & $25.9^{\mathrm{abcd}}(3.9)$ \\
\hline Milk and milk products & $7.1(6.3)$ & $8.3(7.8)$ & $7.1(6.1)$ & $7.0(6.1)$ & $7.4(5.3)$ \\
\hline Legumes & $4.2(3.5)$ & $3.3(3.1)$ & $4.0(4.0)$ & $4.3(3.4)$ & $3.1(2.8)$ \\
\hline Fruit & $2.5^{\mathrm{ae}}(2.7)$ & $2.2^{\text {bf }}(3.1)$ & $3.9^{\text {cef }}(4.1)$ & $4.2^{\text {def }}(4.4)$ & $6.6^{\mathrm{abcd}}(4.9)$ \\
\hline Vegetables (including potato) & $3.7^{\mathrm{ac}}(2.0)$ & $4.3^{\mathrm{bd}}(2.6)$ & $4.1^{\mathrm{ab}}(3.1)$ & $5.0^{\text {cd }}(2.6)$ & $4.2(1.6)$ \\
\hline Added fat & 4.4 (3.3) & $3.9(2.7)$ & $5.6(4.0)$ & $5.7(3.8)$ & $4.9(4.0)$ \\
\hline Alcohol (women) & $8.7(10.0)$ & $9.4(11.3)$ & $7.1(13.1)$ & $5.2(7.9)$ & $1.2(2.3)$ \\
\hline Alcohol (men) & $13.4(16.2)$ & $11.4(10.8)$ & $12.0(14.2)$ & $12.4(16.4)$ & $10.0(9.2)$ \\
\hline
\end{tabular}

Adapted from Maclntyre et al. ${ }^{28}$.

${ }^{a-f}$ Mean values with the same superscript letter differ significantly $(P \leq 0.05)$. 
Table 4 Mean (standard deviation) daily nutrient intakes of men and women by group*

\begin{tabular}{|c|c|c|c|c|c|}
\hline Nutrient & $\begin{array}{c}\text { Group } 1 \\
\text { (194 men, } 290 \text { women) }\end{array}$ & $\begin{array}{c}\text { Group } 2 \\
\text { (109 men, } 148 \text { women) }\end{array}$ & $\begin{array}{c}\text { Group } 3 \\
\text { (128 men, } 172 \text { women) }\end{array}$ & $\begin{array}{c}\text { Group } 4 \\
\text { (229 men, } 292 \text { women) }\end{array}$ & $\begin{array}{c}\text { Group } 5 \\
\text { (83 men, } 106 \text { women) }\end{array}$ \\
\hline \multicolumn{6}{|c|}{ Energy (MJ) } \\
\hline Men & $9.6(0.28)$ & $8.9(0.37)$ & $9.3(0.34)$ & $9.9(0.26)$ & $9.8(0.43)$ \\
\hline Women & $7.9(0.18)$ & $8.0(0.25)$ & $7.9(0.23)$ & $8.0(0.18)$ & $8.5(0.30)$ \\
\hline \multicolumn{6}{|c|}{ Carbohydrate (\% of energy) } \\
\hline Men & $67.4(0.67)$ & $67.2(0.89)$ & $65.5(0.82)$ & $64.0(0.62)$ & $57.3(1.02)$ \\
\hline Women & $67.0(0.54)$ & $68.3(0.75)$ & $64.1(0.70)$ & $61.5(0.54)$ & $55.6(0.89)$ \\
\hline \multicolumn{6}{|c|}{ Fat (\% of energy) } \\
\hline Men & $22.9(0.51)$ & $22.8(0.68)$ & $24.3(0.63)$ & $26.0(0.47)$ & $30.6(0.78)$ \\
\hline Women & $23.6(0.41)$ & $22.6(0.57)$ & $25.6(0.53)$ & $27.7(0.40)$ & $31.8(0.67)$ \\
\hline \multicolumn{6}{|c|}{ Protein ( $\%$ of energy) } \\
\hline Men & $11.6(0.15)$ & $12.1(0.20)$ & $12.0(0.18)$ & $11.8(0.14)$ & $13.2(0.23)$ \\
\hline Women & $11.4(0.13)$ & $11.3(0.18)$ & $11.8(0.16)$ & $12.1(0.12)$ & $13.4(0.21)$ \\
\hline \multicolumn{6}{|c|}{ Animal protein $(\mathrm{g})$} \\
\hline Men & $25.9(1.1)$ & $28.2(1.5)$ & $27.2(1.4)$ & $29.2(1.0)$ & $44.4(1.7)$ \\
\hline Women & $22.2(0.86)$ & $22.1(1.21)$ & $25.9(1.12)$ & $29.1(0.86)$ & $42.6(1.43)$ \\
\hline \multicolumn{6}{|l|}{$\mathrm{P} / \mathrm{S}$ ratio } \\
\hline Men & $1.0(0.03)$ & $0.80(0.04)$ & $1.0(0.03)$ & $0.92(0.02)$ & $0.71(0.04)$ \\
\hline Women & $0.97(0.02)$ & $0.88(0.03)$ & $0.86(0.03)$ & $0.88(0.02)$ & $0.66(0.03)$ \\
\hline \multicolumn{6}{|c|}{ Cholesterol (mg) } \\
\hline Men & $316(16.2)$ & $283(21.6)$ & $332(19.9)$ & $377(14.9)$ & $420(24.7)$ \\
\hline Women & $258(11.7)$ & $241(16.4)$ & $280(15.2)$ & $316(11.7)$ & $332(19.4)$ \\
\hline \multicolumn{6}{|l|}{ Fibre $(g)$} \\
\hline Men & $19.2(0.67)$ & $15.6(0.90)$ & $17.4(0.82)$ & $18.8(0.61)$ & $19.7(1.02)$ \\
\hline Women & $15.8(0.44)$ & $15.4(0.62)$ & $16.3(0.58)$ & $17.1(0.44)$ & $17.7(0.73)$ \\
\hline \multicolumn{6}{|c|}{ Calcium (mg) } \\
\hline Men & 452 (19) & $569(25)$ & $435(23)$ & $422(17)$ & $500(29)$ \\
\hline Women & $348(14)$ & $418(20)$ & $387(18)$ & $405(14)$ & $512(23)$ \\
\hline \multicolumn{6}{|l|}{ Iron (mg) } \\
\hline Men & $9.4(0.3)$ & $7.8(0.4)$ & $9.1(0.4)$ & $9.1(0.3)$ & $10.8(0.5)$ \\
\hline Women & $8.4(0.2)$ & $7.5(0.3)$ & $8.3(0.3)$ & $8.8(0.2)$ & $10.4(0.4)$ \\
\hline \multicolumn{6}{|c|}{ Vitamin A ( $\mu \mathrm{g} R E)$} \\
\hline Men & $610(44)$ & $588(59)$ & $729(55)$ & $762(41)$ & $900(68)$ \\
\hline Women & $573(40)$ & $533(56)$ & $773(52)$ & $892(40)$ & $1246(66)$ \\
\hline \multicolumn{6}{|c|}{ Ascorbic acid (mg) } \\
\hline Men & $30(2.4)$ & $22(3.2)$ & $29(2.9)$ & $37(2.2)$ & $67(3.6)$ \\
\hline Women & $30(2.3)$ & $25(3.2)$ & $32(3.0)$ & $43(2.3)$ & $83(3.8)$ \\
\hline \multicolumn{6}{|c|}{ Folic acid $(\mu \mathrm{g})$} \\
\hline Men & $227(7.4)$ & $187(9.8)$ & $209(9.1)$ & $237(6.8)$ & $244(11.3)$ \\
\hline Women & $181(4.7)$ & $177(6.6)$ & $182(6.1)$ & $209(4.7)$ & $225(7.8)$ \\
\hline
\end{tabular}

Adapted from Macintyre et al. ${ }^{28}$

$\mathrm{P} / \mathrm{S}$ ratio - ratio of polyunsaturated to saturated fatty acids; $\mathrm{RE}$ - retinol equivalents.

${ }^{*}$ For all nutrients (except total energy) rural groups differed significantly from urban groups $(P \leq 0.05)$.

\section{Risk factors for NCDs}

Table 6 gives serum lipid profiles and plasma fibrinogen concentrations of men and women who were uninfected by HIV. Serum total cholesterol (TC) and low-density lipoprotein cholesterol (LDLC) increased significantly ${ }^{31}$ from rural to urban men and women. Serum high-density lipoprotein cholesterol and triglycerides remained relatively constant across groups. Plasma fibrinogen concentrations are given only for the 35.0- to 44.9-year-old age group, illustrating the gradual increase in mean concentration from rural to urban groups ${ }^{32}$. However, mean values in all age groups of men and women in rural and urban locations were above $2.5 \mathrm{gl}^{-1}$, the value usually regarded as the concentration associated with a low risk of cardiovascular disease $\mathrm{s}^{33}$. The mean ( \pm standard deviation) values for all HIV uninfected men and women were $3.17 \pm 1.10$ and $3.64 \pm 1.12 \mathrm{gl}^{-1}$, respectively ${ }^{32}$.

The percentages of men and women who had systolic blood pressure above $140 \mathrm{mmHg}$ and diastolic pressure above $80 \mathrm{mmHg}$ are shown in Table 7 . These varied from $10.4 \%$ (women in group 5) to $34.8 \%$ (men in group 3 ) for systolic pressure and from $13.2 \%$ (women in group 5 and men in group 2) to $26.9 \%$ (women in group 3 ) for diastolic pressure.

Table 8 shows that between $0.8 \%$ (men in group 3 ) and $6.0 \%$ (men in group 5 ) were newly diagnosed as potential diabetics, having fasting or 2-hour blood glucose values above $11.1 \mathrm{mmoll}^{-1}$.

\section{Discussion}

\section{Validity of the study design}

A major objective of this paper is to review data from the THUSA study to show how urbanisation leads to dietary patterns in Africans that increase risk of NCDs. A question that needs consideration, therefore, is how valid is the cross-sectional comparison of rural and urban subjects for this purpose? 
Table 5 Anthropometric (percentage of subjects) and biochemical (estimated means and standard error) indicators of nutritional status of men and women by group

\begin{tabular}{|c|c|c|c|c|c|}
\hline $\begin{array}{l}\text { Nutritional } \\
\text { status } \\
\text { indicator }\end{array}$ & $\begin{array}{c}\text { Group } 1 \\
\text { (196 men, } 300 \text { women) }\end{array}$ & $\begin{array}{c}\text { Group } 2 \\
\text { (117 men, } 147 \text { women) }\end{array}$ & $\begin{array}{c}\text { Group } 3 \\
\text { (135 men, } 176 \text { women) }\end{array}$ & $\begin{array}{c}\text { Group } 4 \\
\text { (236 men, } 292 \text { women) }\end{array}$ & $\begin{array}{c}\text { Group } 5 \\
\text { (84 men, } 106 \text { women) }\end{array}$ \\
\hline \multirow{2}{*}{\multicolumn{6}{|c|}{$\begin{array}{l}\text { Anthropometric } \\
\text { BMl }<18.0 \text { to } 24.9 \mathrm{~kg} \mathrm{~m}^{-2}\end{array}$}} \\
\hline & & & & & \\
\hline Men & 86.7 & 90.6 & 93.3 & 87.3 & 66.7 \\
\hline Women & 52.0 & 46.9 & 52.8 & 38.6 & 38.7 \\
\hline \multicolumn{6}{|c|}{$\mathrm{BMI} \geq 25.0$ to $29.9 \mathrm{~kg} \mathrm{~m}^{-2}$} \\
\hline Men & 8.7 & 6.0 & 3.7 & 8.5 & 30.9 \\
\hline Women & 25.3 & 27.9 & 18.8 & 25.0 & 32.1 \\
\hline \multicolumn{6}{|l|}{$\mathrm{BMI} \geq 30.0 \mathrm{~kg} \mathrm{~m}^{-2}$} \\
\hline Men & 4.6 & 3.4 & 3.0 & 4.2 & 2.4 \\
\hline Women & 22.7 & 25.1 & 28.4 & 36.3 & 29.2 \\
\hline \multicolumn{6}{|l|}{ Waist-to-hip ratio } \\
\hline Men: $>0.95$ & 6.6 & 2.6 & 3.7 & 6.8 & 2.4 \\
\hline Women: $>0.80$ & 9.2 & 4.4 & 4.1 & 9.2 & 1.3 \\
\hline \multicolumn{6}{|l|}{ Biochemical } \\
\hline \multicolumn{6}{|c|}{ Total iron-binding capacity $\left(\mu \mathrm{g} \mathrm{dl}^{-1}\right)$} \\
\hline Men & $64.3^{\mathrm{a}}(1.2)$ & $66.5^{\mathrm{b}}(1.6)$ & $64.2^{\mathrm{C}}(1.3)$ & $63.9^{d}(1.0)$ & $73.1^{\mathrm{abcd}}(1.6)$ \\
\hline Women & $66.8^{\mathrm{a}}(0.9)$ & $67.2^{\mathrm{b}}(1.6)$ & $68.0^{c}(1.0)$ & $70.2^{d}(0.9)$ & $76.6^{\text {abcd }}(1.4)$ \\
\hline \multicolumn{6}{|c|}{ Transferrin saturation (\%) } \\
\hline Men & $28.1^{\mathrm{a}}(1.4)$ & $27.6^{b}(1.8)$ & $31.7(1.4)$ & $32.5^{\mathrm{ab}}(1.2)$ & $28.4(1.8)$ \\
\hline Women & $23.3(0.9)$ & $25.5(1.6)$ & $24.3(1.0)$ & $21.9(0.9)$ & $22.9(1.3)$ \\
\hline \multicolumn{6}{|c|}{ Serum ferritin $\left(\mu \mathrm{gl}^{-1}\right)$} \\
\hline Men & $231(32)$ & $172(41)$ & $179(32)$ & $213(27)$ & $178(42)$ \\
\hline Women & $103(13)$ & $118(23)$ & $82(15)$ & 76 (13) & $62(20)$ \\
\hline \multicolumn{6}{|c|}{ Haemoglobin $\left(\mathrm{g} \mathrm{dl}^{-1}\right)$} \\
\hline Men & $14.4^{\mathrm{a}}(0.2)$ & $13.5^{\mathrm{b}}(0.3)$ & $13.8^{c}(0.2)$ & $13.4^{\mathrm{d}}(0.2)$ & $13.2^{\mathrm{abcd}}(0.3)$ \\
\hline Women & $13.0^{\mathrm{a}}(0.2)$ & $12.6^{\mathrm{b}}(0.3)$ & $12.1^{\mathrm{c}}(0.2)$ & $12.2^{d}(0.1)$ & $11.6^{\text {abcd }}(0.2)$ \\
\hline \multicolumn{6}{|c|}{ Serum retinol $\left(\mu \mathrm{g} \mathrm{dl}^{-1}\right)$} \\
\hline Men & $46.4^{\mathrm{a}}(1.5)$ & $46.1^{\mathrm{b}}(2.0)$ & $49.5^{\mathrm{c}}(1.6)$ & $47.5(1.3)$ & $53.4^{\mathrm{abc}}(2.1)$ \\
\hline Women & $44.8(1.1)$ & $44.1(2.0)$ & $43.6(1.2)$ & $45.6(11)$ & $45.0(1.6)$ \\
\hline
\end{tabular}

Adapted from Van Rooyen et al. ${ }^{29}$ and Kruger et al. ${ }^{30}$

a-d Mean values with the same superscript letter differ significantly $(P \leq 0.05)$.

A prospective study, following subjects in transition over time, would have been more ideal. However, the pressing need for information made this design impractical. The validity of comparisons between the rural and urban subjects in this study depends on whether the rural subjects actually had more 'traditional' lifestyles compared with more modern, Westernised lifestyles of urban subjects. Modernisation or Westernisation is a two-way

Table 6 Mean (95\% confidence interval or standard deviation) levels of biochemical risk factors for non-communicable diseases in men and women uninfected with HIV by group

\begin{tabular}{|c|c|c|c|c|c|}
\hline Risk factor & $\begin{array}{c}\text { Group } 1 \\
\text { (76 men, } 258 \text { women) }\end{array}$ & $\begin{array}{c}\text { Group } 2 \\
\text { (104 men, } 130 \text { women) }\end{array}$ & $\begin{array}{c}\text { Group } 3 \\
\text { (115 men, } 142 \text { women) }\end{array}$ & $\begin{array}{c}\text { Group } 4 \\
\text { (171 men, } 245 \text { women) }\end{array}$ & $\begin{array}{c}\text { Group } 5 \\
\text { (54 men, } 87 \text { women) }\end{array}$ \\
\hline \multicolumn{6}{|c|}{ Serum total cholesterol $\left(\mathrm{mmoll}^{-1}\right)$} \\
\hline Men & $3.91^{\mathrm{a}}(3.89-4.24)$ & $4.07^{\mathrm{b}}(3.71-4.05)$ & $3.88^{\mathrm{C}}(3.86-4.14)$ & $4.00^{d}(3.96-4.10)$ & $4.79^{\mathrm{abcd}}(4.54-5.04)$ \\
\hline Women & $4.05^{\mathrm{abc}}(3.94-4.17)$ & $4.12^{\mathrm{a}}(3.95-4.29)$ & $4.21^{\text {de }}(4.05-4.37)$ & $4.47^{\text {bd }}(4.35-4.60)$ & $4.79^{\mathrm{ce}}(4.59-5.00)$ \\
\hline \multicolumn{6}{|c|}{ High-density lipoprotein cholesterol $\left(\mathrm{mmol}^{-1}\right)$} \\
\hline Men & $1.22(1.16-1.28)$ & $1.18(1.10-1.25)$ & $1.23(1.15-1.30)$ & $1.22(1.16-1.28)$ & $1.23(1.12-1.34)$ \\
\hline Women & $1.18(1.14-1.21)$ & $1.17(1.12-1.23)$ & $1.15^{\mathrm{a}}(1.10-1.20)$ & $1.15^{\mathrm{b}}(1.11-1.19)$ & $1.24^{\mathrm{ab}}(1.17-1.30)$ \\
\hline \multicolumn{6}{|c|}{ Low-density lipoprotein cholesterol $\left(\mathrm{mmoll}^{-1}\right)$} \\
\hline Men & $2.33^{\mathrm{a}}(2.19-2.47)$ & $2.45^{\mathrm{b}}(2.27-2.63)$ & $2.22^{\mathrm{c}}(2.05-2.39)$ & $2.37^{d}(2.23-2.51)$ & $3.10^{\mathrm{abcd}}(2.85-3.35)$ \\
\hline Women & $2.50^{\mathrm{abc}}(2.38-2.71)$ & $2.54^{a}(2.46-2.77)$ & $2.61^{\mathrm{d}}(2.77-3.01)$ & $2.89^{\mathrm{bd}}(2.85-3.25)$ & $3.05^{\mathrm{c}}(2.62-2.75)$ \\
\hline \multicolumn{6}{|c|}{ Serum triglycerides $\left(\mathrm{mmoll}^{-1}\right)$} \\
\hline Men & $1.02(0.85-1.18)$ & $1.02(0.75-1.28)$ & $1.10(0.90-1.26)$ & $1.19(1.04-1.33)$ & $1.38(0.88-1.88)$ \\
\hline Women & $0.98^{\mathrm{a}}(0.87-1.10)$ & $1.09(0.94-1.24)$ & $1.04(0.89-1.19)$ & $1.17^{\mathrm{a}}(1.07-1.28)$ & $0.87(0.35-1.39)$ \\
\hline \multicolumn{6}{|c|}{ Plasma fibrinogen $\left(g \mathrm{I}^{-1}\right)^{\star}$} \\
\hline Men & $2.91(0.93)$ & $3.63(0.77)$ & $3.70(1.23)$ & $2.96(0.90)$ & $3.64(1.03)$ \\
\hline Women & $3.38(0.87)$ & $3.76(0.85)$ & $3.69(1.25)$ & $3.84(1.04)$ & $3.97(0.81)$ \\
\hline
\end{tabular}

Adapted from Oosthuizen et al..$^{31}$ and James et al. ${ }^{32}$.

* In the age group 35.0-44.9 years.

${ }^{a-d}$ Mean values with the same superscript letter differ significantly $(P \leq 0.05)$. 
Table 7 Rates of hypertension expressed as percentage of subjects who had systolic/diastolic blood pressure (BP) greater than $140 / 90 \mathrm{mmHg}$ by group

\begin{tabular}{|c|c|c|c|c|c|}
\hline Variable & $\begin{array}{c}\text { Group } 1 \\
\text { (198 men, } 299 \text { women) }\end{array}$ & $\begin{array}{c}\text { Group } 2 \\
\text { (114 men, } 149 \text { women) }\end{array}$ & $\begin{array}{c}\text { Group } 3 \\
\text { (132 men, } 175 \text { women) }\end{array}$ & $\begin{array}{c}\text { Group } 4 \\
\text { (232 men, } 294 \text { women) }\end{array}$ & $\begin{array}{c}\text { Group } 5 \\
\text { (84 men, } 106 \text { women) }\end{array}$ \\
\hline \multicolumn{6}{|c|}{ Systolic BP >140 mmHg } \\
\hline Men & 19.2 & 13.2 & 34.8 & 23.3 & 17.9 \\
\hline Women & 22.1 & 28.2 & 31.4 & 31.3 & 10.4 \\
\hline \multicolumn{6}{|c|}{ Diastolic BP >90 mmHg } \\
\hline Men & 14.6 & 13.2 & 22.7 & 19.0 & 22.6 \\
\hline Women & 21.4 & 21.5 & 26.9 & 25.9 & 13.2 \\
\hline
\end{tabular}

Adapted from Van Rooyen et al. ${ }^{29}$.

process: the rural subjects were exposed to Western influences by migrant workers returning home, by radio and improvements of rural infrastructures (roads, health services, electricity and water provisions, development of markets, shops, etc.). Nevertheless, Table 1 shows that there were major differences in several 'lifestyle' indicators between rural and urban subjects, suggesting that comparison of nutrition and health status between them probably reflects the influences of urbanisation. Moreover, this baseline survey also provided information about nutrition and health problems that need attention in the participating communities. The rest of the discussion focuses on some of the salient results that illustrate the impact of urbanisation on nutrition and health status, after which implementation and follow-up actions are briefly presented.

\section{Changes in dietary patterns and nutritional status}

The decreased intake of the staple food, maize porridge, and the increased intakes of animal-derived foods and added fats/oils with urbanisation (Tables 2 and 3) confirm the dietary patterns observed in other developing countries $^{34}$. The resultant changes in nutrient intakes (Table 4) - i.e. the decrease in total carbohydrate, increases in animal protein and total fat, and decrease in the $\mathrm{P} / \mathrm{S}$ ratio - agree with earlier comparisons of nutrient intakes between rural and urban South Africans ${ }^{35}$. The lower intake of foods from the carbohydrate-rich group was not accompanied by decreases in dietary fibre intake (Table 4). The reason is probably the gradual but substantial increase in fruit and vegetable intakes. These increases, together with the increase in animal foods, were

Table 8 Percentage of newly diagnosed diabetes mellitus* subjects per group

\begin{tabular}{lccccc}
\hline & Group 1 & Group 2 & Group 3 & Group 4 & Group 5 \\
\hline Men & 3.6 & 4.4 & 0.8 & 1.3 & 6.0 \\
Women & 5.0 & 4.1 & 5.1 & 5.1 & 4.7 \\
\hline
\end{tabular}

Adapted from Vorster et al. ${ }^{4}$.

*Based on a blood glucose concentration $>11.1 \mathrm{mmoll}^{-1}$ either at fasting or after $2 \mathrm{~h}$ during a glucose tolerance test. probably responsible for the improved micronutrient intakes (Table 4) and micronutrient status (Table 5) of the subjects in group 5 (the more affluent urban group). MacIntyre et $a l{ }^{28}$ pointed out that despite these increases in fruit and vegetable intakes, intakes were low in all groups and not reach the recommended minimum of $400 \mathrm{~g} \mathrm{day}^{-1}$. The reasons are probably the harsh climate, lack of water, poor soil and other resources in rural areas, while price may be the main constraint in urban areas ${ }^{28}$. Nevertheless, it seems that an improvement in micronutrient intakes and status is a major positive effect of urbanisation on $\operatorname{diet}^{30}$.

\section{Emergence of NCDs}

The observed increases in serum TC, LDLC and plasma fibrinogen, all accepted risk factors of cardiovascular disease that can be influenced by $\operatorname{diet}^{31,33}$, are major negative effects of urbanisation. An analysis of the lipid risk factors of the THUSA population by Oosthuizen et al. ${ }^{31}$ showed that although levels were relatively low in most groups, the urban groups already had levels that need intervention to protect against future cardiovascular disease. In their analysis, they showed that both TC and LDLC were related to obesity and low activity, especially in women ${ }^{31}$. James et al. ${ }^{32}$ similarly showed that obesity in the THUSA women was related to their high plasma fibrinogen. These authors also showed that in men, a low micronutrient intake and status was significantly related to high plasma fibrinogen. These results suggests that urbanisation may have a positive effect on NCD risk by improving micronutrient (antioxidant?) status (at least in lean men) but that the obesity associated with urbanisation could be the main determinant of the increases observed in NCD risk factors.

The African population is known to be vulnerable to hypertension ${ }^{36}$, stroke $^{37}$ and diabetes mellitus ${ }^{38}$. Nevertheless, the $10.4-28.2 \%$ of subjects in the different groups who were identified as possibly hypertensive, and the $0.8-6.0 \%$ of subjects identified as possible diabetics, in this sample of apparently healthy subjects, is of concern. In rural areas it may reflect the inaccessibility of health services, and in urban areas it may reflect a lack of awareness and knowledge to seek help from available 
clinics. Van Rooyen et $a .^{29}$ showed in the THUSA population that blood pressure correlated positively and significantly with age, level of urbanisation, waist-to-hip ratio and smoking. In women, diastolic blood pressure correlated positively and significantly with BMI, serum lipids and serum $\boldsymbol{\gamma}$-glutamyl transferase, a marker of alcohol intake. In both groups, psychological strengths and coping strategies were related to blood pressure, especially in women ${ }^{29}$.

\section{Obesity}

Obesity seems to be the main underlying factor in NCD risk in this population. The significant impact of urbanisation on overweight in men is clear (Table 5), although the obesity rate in men is still low. In women, overweight and obesity rates in both rural and urban women were high: 48.0, 53.0, 47.2, 61.3 and 61.3\% in groups 1 to 5 . Therefore, urbanisation effects are also apparent in women. Kruger et al. ${ }^{39-41}$ analysed the causes and consequences of these high rates. Their results showed that household income, total energy intake, fat intake and low physical activity were the major determinants of obesity and that a number of cardiovascular risk factors were associated with obesity. These results emphasise the urgent need for culturally sensitive interventions to promote physical activity and low-energy but nutrient-dense diets.

\section{The vulnerability of farm workers}

Subjects from group 2, living and working on commercial farms, consistently showed the lowest nutrient intakes and lowest nutrition, physical and mental health status. The mental health outcomes measured (Table 1) showed that farm dwellers had significantly higher levels of distress and symptomatology, having the highest score on all facets of the NEOPI-R (anxiety, angry hostility, depression, self-consciousness, impulsiveness and vulnerability) ${ }^{4}$. It was also shown that the inability to cope with changes during urbanisation influenced the development of hypertension in these subjects ${ }^{29}$, and that women suffered more than $m^{4}{ }^{4}$. These results are important inter alia for two reasons. First, they identified farm dwellers and women as the most vulnerable groups with the most urgent need for intervention, empowerment and health promotion programmes. But they also focused on the need for examining in more depth psychological strengths and coping abilities to adapt to the changes during urbanisation.

\section{Implementation and follow-up actions}

The THUSA study was immediately followed by the design and implementation of an ongoing transdisciplinary, multi-sectoral intervention programme in farm dwellers, aimed to improve quality of life (the FLAGH - Farm Labourer and General Health - programme ${ }^{42}$.
Because the THUSA study recruited subjects from 15 years and older, and the national food consumption survey children from 1 to 9 years, the THUSABANA (THUSA and BANA for children) study ${ }^{43}$ was planned and implemented to gather data on a random sample of children aged 9-15 years in the North West Province.

This study gave birth to the PLAY (Physical Activity in the Young) study ${ }^{44}$ in which the effects of physical activity in stunted children are being examined.

To examine the causes and consequences of obesity in women, the POWIRS (Profiles of Women with Insulin Resistance) studies ${ }^{45}$ were done, comparing obese and lean women from different ethnic groups in the metabolic unit of the North-West University.

The relationships between the nutritional status of pregnant women and birth outcomes were examined in the THUSAMAMA (THUSA and MAMA for mothers) study ${ }^{46}$.

The THUSA study identified the need for the availability of a larger variety of healthy foods and products using indigenous foods as basis. Several studies to develop and test such products are underway in the nutrition laboratory of the University in the programme on functional foods.

The THUSA study is now being followed with a 12-year prospective study, namely PURE (Prospective Urban and Rural Epidemiology).

\section{Conclusions}

The THUSA study, designed to examine the impact of urbanisation on nutrition and health status, showed that in some aspects urbanisation was associated with better physical (micronutrient status) and mental health. But it also showed that urbanisation leads to an increase in overweight and obesity with accompanying increases in risk factors for NCDs. These results should influence prevention strategies and programmes. Furthermore, the THUSA study identified several areas for more in-depth research that could lead to a better understanding of the nutrition and health transition in South Africa.

\section{References}

1 Baron P. Equity in 1998: an overview. In: Ntuli A, ed. South African Health Review, 1998. Durban: Health Systems Trust, 1998; 1-6.

2 Health Systems Trust. South African Health Review 2002. Durban: Health Systems Trust, 2002; 546p.

3 Vorster HH, Bourne LT, Venter CS, Oosthuizen W. Contribution of nutrition to the health transition in developing countries: a framework for research and intervention. Nutrition Reviews 1999; 57(11): 341-9.

4 Vorster HH, Wissing MP, Venter CS, Kruger HS, Kruger A, Malan NT, et al. The impact of urbanization on physical physiological and mental health of Africans in the North 
West Province of South Africa: the THUSA study. South African Journal of Science 2000; 96: 505-13.

5 MacIntyre UE, Venter CS, Vorster HH. A culture-sensitive quantitative food frequency questionnaire used in an African population: 1. Development and reproducibility. Public Health Nutrition 2000; 4(1): 53-62.

6 MacIntyre UE, Venter CS, Vorster HH. A culture-sensitive quantitative food frequency questionnaire used in an African population: 2. Relative validation by 7 -day weighed records and biomarkers. Public Health Nutrition 2000; 4(1): 63-71.

7 MacIntyre UE, Venter CS, Vorster HH, Steyn HS. A combination of statistical methods for the analysis of the relative validation data of the quantitative food frequency questionnaire used in the THUSA study. Public Health Nutrition 2000; 4(1): 45-51.

8 Venter CS, MacIntyre UE, Vorster HH. The development and testing of a food portion photograph book for use in an African population. Journal of Human Nutrition and Dietetics 2000; 13(3): 205-18.

9 Langenhoven M, Kruger M, Gouws E, Faber M. MRC Food Consumtion Tables, 3rd ed. Parow: Medical Research Council, 1991.

10 Willett WC, Howe GR, Kushi LH. Adjustment for total energy intake in epidemiological studies. American Journal of Clinical Nutrition 1997; 65(Suppl. 4): 1220S-8S.

11 Kruger HS, Venter CS, Steyn HS Jr. A standardised physical activity questionnaire for a population in transition: the THUSA study. African Journal for Physical Health Education 2000; 6(1): 54-64.

12 Goldberg DP, Hillier VF. A scaled version of the General Health Questionnaire. Psychological Medicine 1979; 9(1): $139-45$.

13 Kammann NR, Flett R. Affectometer 2: a scale to measure current level of general happiness. Australian Journal of Psychology 1983; 35: 259-65.

14 Antonovsky A. Unravelling the Mystery of Health: How People Manage Stress and Stay Well. San Francisco, CA: Jossey-Bass, 1987.

15 Diener E, Emmons RA, Larson RJ, Griffen S. The satisfaction with life scale. Journal of Personality Assessment 1985; 49: $71-5$.

16 Carver CS, Scheier MF, Weintraub JK. Assessing coping strategies: a theoretically based approach. Journal of Personality and Social Psychology 1989; 56(2): 267-83.

17 Hobfoll SE, Dunahoo CL, Monier J. Preliminary Test Manual: Strategic Approach to Coping (SACS). Kent, OH: Applied Psychology Center, Kent State University, 1994/5.

18 Costa PT, McCrae RR. NEO PI-R: Professional Manual. Odessa, FL: Psychological Assessment Resources, 1992.

19 Buss AH, Durkee A. An inventory for assessing different kinds of hostility. Journal of Consulting Psychology 1957; 21(4): 343-8.

20 Cohen S, Kamarck T, Mermelstein R. A global measure of perceived stress. Journal of Health and Social Behavior 1983; 24(4): 385-96.

21 Procidano ME, Heller K. Measures of perceived social support from friends and from family: three validation studies. American Journal of Community Psychology 1983; 11(1): $1-24$.

22 Landrine H, Klonoff EA. The African American Acculturation Scale: development reliability and validity. Journal of Black Psychology 1994; 20: 104-27.

23 Triandis HC, Botempo R, Betancourt H, Bond M, Leung K, Brenes A, et al. The measurement of the ethic aspects of individualism and collectivism across cultures. Australian Journal of Psychology 1986; 38: 257-67.

24 Lemke S, Vorster HH, Jansen Van Rensburg NS, Ziche J. Empowered women, social networks and the contribution of qualitative research: broadening our understanding of underlying causes for food and nutrition insecurity. Public Health Nutrition 2003; 6(8): 759-64.

25 Burger HM. Changes in risk factors of breast cancer in African women during urbanisation. MSc dissertation, Potchefstroom University for Christian Higher Education, South Africa, 1998

26 Nell TA. Changes in dietary risk factors of colon cancer in Africans during urbanisation. MSc dissertation, Potchefstroom University for Christian Higher Education, South Africa, 1998.

27 Vorster HH Jr, Venter CS, Kruger MC, Vorster HH, Kruger HS. The impact of urbanisation on risk factors for osteoporosis in postmenopausal black South African women. Journal of Endocrinology, Metabolism and Diabetes of South Africa 2002; 7(3): 92-9.

28 MacIntyre UE, Kruger HS, Venter CS, Vorster HH. Dietary intakes of an African population in different stages of transition in the North West Province, South Africa: the THUSA study. Nutrition Research 2002; 22: 239-56.

29 Van Rooyen JM, Kruger HS, Huisman HW, Wissing MP, Margetts BM, Venter CS, et al. An epidemiological study of hypertension and its determinants in a population in transition: the THUSA study. Journal of Human Hypertension 2000; 14(12): 779-87.

30 Kruger HS, Kruger A, Vorster HH, Jooste PL, Wolmarans P. Urbanization of Africans in the North West Province is associated with better micronutrient status: the Transition and Health during Urbanization Study in South Africa. Nutrition Research 2005; 25: 365-75.

31 Oosthuizen W, Vorster HH, Kruger A, Venter CS, Kruger HS, De Ridder JH. Impact of urbanisation on serum lipid profiles - the THUSA survey. South African Medical Journal 2002; 92(9): 723-8.

32 James S, Vorster HH, Venter CS. Nutritional status influences plasma fibrinogen concentration: evidence from the THUSA survey. Thrombosis Research 2000; 98(5): 383-94.

33 Vorster HH, Cummings JH, Veldman FJ. Diet and haemostasis: time for nutrition science to get more involved. British Journal of Nutrition 1997; 77(5): 671-84.

34 Drenowski A, Popkin BM. The nutrition transition: trends in the global diet. Nutrition Reviews 1997; 55(2): 31-43.

35 Vorster HH, Oosthuizen W, Jerling JC, Veldman FJ, Burger HM. Nutritional Status of South Africans. A Review of the Literature from 1975-1996. Durban: Health Systems Trust, 1997; 122 pp.

36 Steyn K, Fourie J, Lombard C, Katzenellenbogen J, Bourne L, Jooste P. Hypertension in the black community of the Cape Peninsula, South Africa. East African Medical Journal 1996; 73(11): 758-63.

37 Wyndham $\mathrm{CH}$. Mortality from cardiovascular diseases in the various population groups in the Republic of South Africa. South African Medical Journal 1979; 56(24): 1023-30.

38 Mollentze WF, Moore A, Oosthuizen GM. The prevalence of diabetes mellitus in two South African black populations [abstract]. Diabetologia 1992; 35(Suppl. 1): S11.

39 Kruger HS, Venter CS, Vorster HH. Obesity in African women in the North West Province, South Africa, is associated with an increased risk of non-communicable diseases: the THUSA study. British Journal of Nutrition 2001; 86(6): 733-40.

40 Kruger HS, Venter CS, Vorster HH, Margetts BM. Physical activity is the major determinant of obesity in black women in the North West Province, South Africa: the THUSA study. Nutrition 2002; 18(5): 422-7.

41 Kruger HS, Venter CS, Vorster HH. Physical inactivity as a risk factor for cardiovascular disease in communities undergoing rural to urban transition: the THUSA study. Cardiovascular Journal of South Africa 2003; 14(1): 16-23.

42 Phometsi M, Kruger A, Van't Riet H. Nutrition knowledge and barriers to dietary practices among school children in a 
farming community - FLAGH programme. Development South Africa 2005; in press.

43 Mukuddem-Petersen J, Kruger HS. Association between stunting and overweight among 10-15 year old children in the North West Province of South Africa: the THUSA BANA study. International Journal of Obesity and Related Metabolic Disorders 2004; 28(7): 842-51.

44 Kruger HS, De Ridder JH, Underhay C. Prediction of body fat based on skinfold thickness provides satisfactory estimates of body fat percentage in grade 8 black children [abstract].
Presented at International Association for the Study of Obesity: First Regional Congress, Sun City, South Africa, 28-31 October 2004

45 Schutte AE, Kruger HS, Wissing MP, Underhay C, Vorster HH The emergence of the metabolic syndrome in urban obese African women: the POWIRS study. South African Journal of Science 2005; 101: 61-7.

46 Kruger HS. Pregnancy outcomes of overweight and normal weight women in a South African outpatient clinic. Journal of Human Ecology 2005; 13: 61-8. 